\title{
Meta-Analysis the Effects of Obesity and Type 2 Diabetes Mellitus on Covid-19 Mortality
}

\author{
Oktaviana Kurniawati'), Hanung Prasetya²), Bhisma Murti') \\ 1)Masters Program in Public Health, Universitas Sebelas Maret \\ ${ }^{2)}$ Health Polytechnics, Ministry of Health Surakarta
}

\section{ABSTRACT}

Background: COVID-19 is a disease caused by a new coronavirus called SARS-CoV-2. In more severe cases, COVID-19 can cause death. The most severe COVID-19 patient mortality is associated with underlying health conditions. The most common associated comorbidities are pulmonary disease, diabetes, obesity and old age. However, the effects of obesity and T2DM disease on the 2019 coronavirus disease (COVID-19) pandemic are controversial. This study aims to analyze the magnitude of the influence of obesity and T2DM on COVID-19 mortality.

Subjects and Method: This study uses a systematic review and meta-analysis research design. The time of the selected test results is between January 2020 to January 2021. The search for articles is carried out for 1 month. Research data was searched from databases: PubMed, Google Scholar, JAMA, Willey and Science Direct. Using search keywords: (Type 2 diabetes mellitus OR diabetic) AND (mortality OR death) AND (COVID-19 /OR Coronavirus OR SARS-CoV-2) AND ("adjusted odds ratio" OR "aOR"), (obesity OR obese) AND (mortality OR death) AND (COVID-19 OR Coronavirus OR SARS-CoV-2) AND ("adjusted odds ratio" OR "aOR"). The inclusion criteria in this study were full text articles in English, observational study designs were collected using PRISMA, and analyzed using the Review Manager application (RevMan 5.3).

Results: A total of 15 articles were reviewed in this study. A meta-analysis of 10 cohort studies showed that people with COVID19 who had comorbid obesity were 1.50 times more likely to die from COVID-19 compared to those without obesity $(\mathrm{aOR}=1.5 \mathrm{O} ; 95 \% \mathrm{CI}=1.17$ to $1.93 ; \mathrm{p}=$ o.001). A meta-analysis of 6 cohort studies showed people with COVID-1919 who had comorbid T2DM 1.93 times to die from COVID19 compared with those without T2DM (aOR = $1.93 ; 95 \% \mathrm{CI}=1.28$ to $2.90 ; \mathrm{p}=0.002$ ).

Conclusion: Obesity and T2DM are predictors of COVID19 mortality.

Keywords: obesity, type 2 diabetes mellitus, mortality, COVID 19

\section{Correspondence:}

Oktaviana Kurniawati. Masters Program in Public Health, Universitas Sebelas Maret. Jl. Ir. Sutami 36A, Surakarta 57126, Central Java. Email: oktaniawati94@gmail.com. Mobile: 085865463742 .

Cite this as:

Kurniawati O, Prasetya H, Murti B (2021). Meta-Analysis the Effects of Obesity and Type 2 Diabetes Mellitus on Covid-19 Mortality. J Epidemiol Public Health. 06(02): 177-191. https://doi.org/10.26911/jepublichealth.2021.06.02.05.

Journal of Maternal and Child Health is licensed under a Creative Commons Attribution-NonCommercial-ShareAlike 4.0 International License.

\section{BACKGROUND}

In early 2020, the world was shocked by the emergence of new infectious diseases (Huang et al., 2020). WHO named the disease caused by this Novel Coronavirus as COVID-19 (Binti Hamzah et al., 2020).
Since the first case in Wuhan, there has been an increase in cases in China every day and peaked between late January to early February 2020. Data on February 3, 2021 shows that there are 1.09 million confirmed cases and 30,277 deaths. The 
mortality rate for COVID-19 in Indonesia is $2.7 \%$. While data for the world, there are 103 million cases with a total death of 2.24 million (WHO, 2021).

A retrospective study based on hospital data from the Jakarta Health Service, a sample of 4,265 adults and children with COVID-19 were treated at 55 referral hospitals, during the first five months of the epidemic. Overall mortality was $12 \%$ (497/ 4,265), and deaths occurred at all ages. The increased risk of death in hospital is associated with increasing age and with the presence of one or more chronic comorbidities, which was recorded in $31 \%$ of patients (Setiati \& Azwar, 2020).

In a study in Wuhan, the mortality rate from COVID-19 pneumonia was concentrated in patients over the age of 65 , especially those with comorbidities. The most severe COVID-19 patient mortality is associated with underlying health conditions. The most common associated comorbidities are lung disease, diabetes, and old age (Knowns, 2020).

Obese people have a higher risk of COVID-19 and a poorer prognosis than those who are not obese (Hajifa-thalian et al, 2020; Onder et al, 2020). In a study by Ranil et al, COVID-19 mortality was significantly correlated with prevalence obesity (Jayawardena et al., 2020). Deaths in people with type 1 and type 2 diabetes rose sharply during the start of the COVID-19 pandemic in the UK. The increase in COVID-19-related mortality is not only associated with cardiovascular and renal complications of diabetes, but also with glycemic control and BMI (Holman et al., 2020b).

The effects of obesity on the COVID-19 disease pandemic are controversial (Cornejo et al, 2020). In addition, patients with T2DM tend to develop severe and critically ill, but there is no clear difference in mortality between patients with COVID19 with and without T2DM (Wang et al., 2020).

Various studies have been conducted to look at the effect of obesity and T2DM as predictors of COVID-19 mortality, but the results of these studies still do not show consistent results. Further analysis is needed to reach convincing conclusions about the influence of obesity and T2DM as predictors of COVID19 mortality.

\section{SUBJECTS AND METHOD}

\section{Study Design}

This study uses a systematic review and meta-analysis with PRISMA flow diagram guidelines. Search articles using databases: PubMed, Google Scholar, JAMA, Willey and Science Direct and were carried out within 1 month. Search keywords used: (Type 2 diabetes mellitus OR diabetic) AND (mortality OR death) AND (COVID-19 /OR Coronavirus OR SARS-CoV-2) AND ("adjusted odds ratio" OR "aOR"), (obesity OR obese) AND (mortality OR death) AND (COVID-19 OR Coronavirus OR SARS-CoV2) AND ("adjusted odds ratio" OR "aOR").

\section{Inclusion Criteria}

The authors developed inclusion criteria, namely an observational study design published from January 2020 to January 2021. The selected articles discussed the influence of obesity and T2DM as predictors of mortality in COVID19 patients. The articles used are articles published in English. The study sample was people infected with COVID19. The research data are multivariate. The final results of this study are reported using an adjusted odds ratio (aOR).

\section{Exclusion Criteria}

The exclusion criteria in this study were non-observational studies, the articles were not full text and were not published in English. 


\section{Operational Definition of Variables}

In formulating research problems, researchers use PICO. Population is people infected with COVID19. Intervention is having comorbid obesity and T2DM, with a comparison that is not having comorbid obesity and T2DM and the outcome is death from COVID19.

Obesity is the accumulation of excessive fat due to an imbalance in energy intake with energy used for a long time.

T2DM is a chronic disease that occurs either when the pancreas does not produce enough insulin or when the body cannot effectively use the insulin it produces.

Mortality is the permanent loss of all signs of life at any time after live birth, i.e. the loss of life functions after birth, without the possibility of resuscitation.

\section{Study Instrument}

The research was conducted using the PRISMA flow diagram guidelines and the assessment of the quality of research articles using the Critical Appraisal Checklist for Cohort Study tools (CEBMa, 2014).

\section{Data Analysis}

The data in this study were analyzed using the RevMan 5.3 application, to calculate the effect size and heterogeneity of the study. The results of data processing are presented in the form of forest plots and funnel plots.

\section{RESULTS}

The article review process was carried out using the PRISMA flow chart, which can be seen in Figure 1. The total articles obtained were 15 articles. The distribution of the article is on 5 continents with details 3 from Asia, 7 from North America, 1 from Africa, 1 from South America and 3 from Europe. Figure 2 shows the areas of the articles taken that match the inclusion criteria.

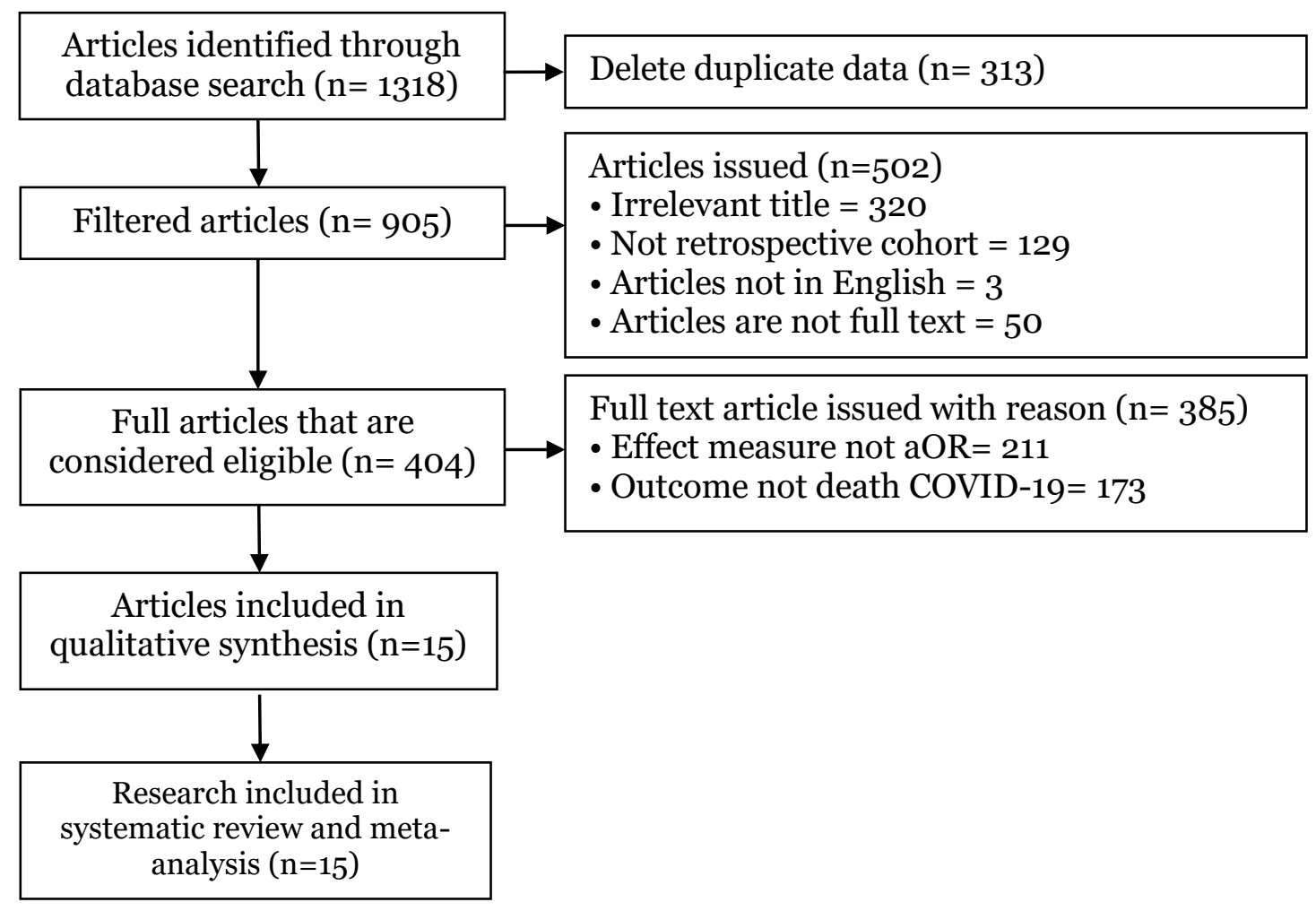

Figure 1. PRISMA flow diagram 


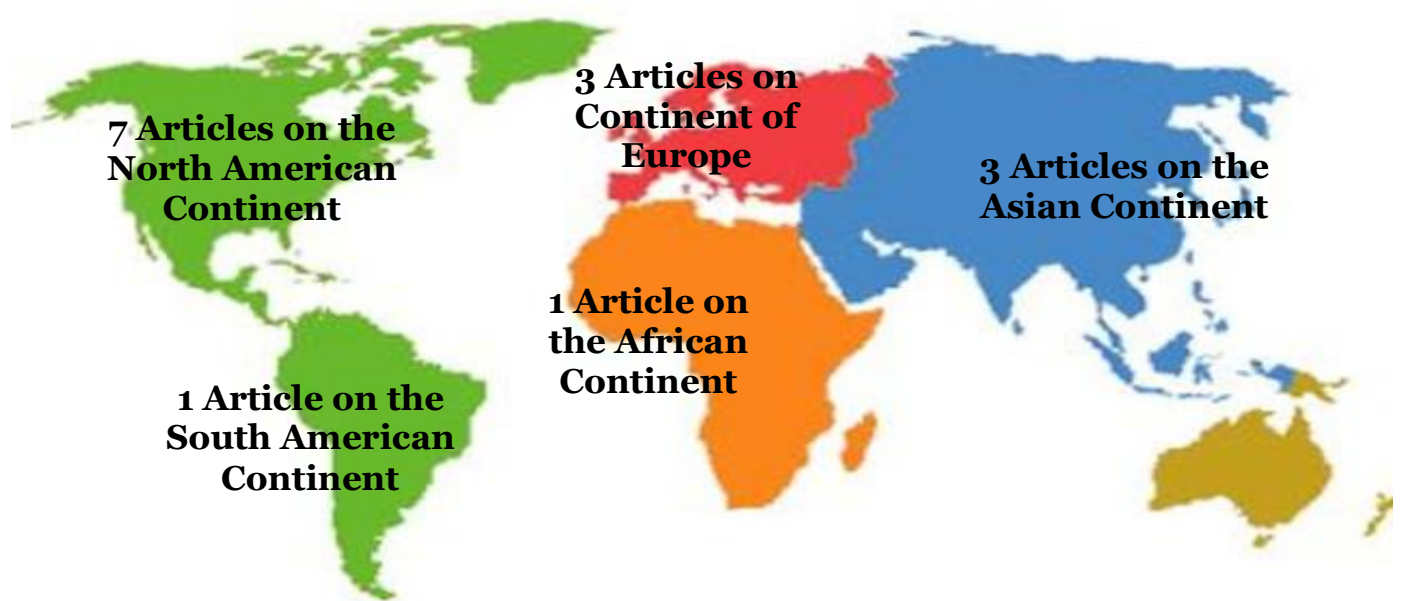

Figure 2. Distribution of Primary Research by Continent

The assessment of the quality of the primary study was carried out quantitatively and qualitatively which can be seen in Table 1 below. This research was conducted using the Critical Appraisal Checklist for Cohort Study sourced from the Center for Evidence Based Management (CEBMa, 2014).

Table 1. Quality Assessment of Cohort Study Design Articles

\begin{tabular}{|c|c|c|c|c|c|c|c|c|c|c|c|c|c|}
\hline \multirow{2}{*}{ Primary Study } & \multicolumn{12}{|c|}{ Criteria } & \multirow{2}{*}{ Total } \\
\hline & $\mathbf{1}$ & 2 & 3 & 4 & 5 & 6 & 7 & 8 & 9 & 10 & 11 & 12 & \\
\hline Id et al. (2021) & 1 & 1 & 1 & 1 & 1 & 0 & 1 & 0 & 1 & 1 & 1 & 1 & 1 \\
\hline Hoobs et al. (2021) & 1 & 1 & 1 & O & 1 & 1 & 1 & 0 & 1 & 1 & 1 & 1 & 10 \\
\hline Satman et al. (2021) & 1 & 1 & 1 & O & 1 & 1 & 1 & 1 & 1 & 1 & 1 & 1 & 11 \\
\hline Barron et al. (2020) & 1 & 1 & 1 & 1 & 1 & 1 & 1 & 0 & 1 & 1 & 1 & 1 & 11 \\
\hline $\begin{array}{l}\text { Czernichow et al. } \\
(2020)\end{array}$ & 1 & 1 & 1 & 1 & 1 & 1 & 1 & $\mathrm{O}$ & 1 & 1 & 1 & 1 & 11 \\
\hline Seiglie et al. (2020) & 1 & 1 & 1 & $\mathrm{O}$ & 1 & 1 & 1 & 1 & 1 & 1 & 1 & 1 & 11 \\
\hline Ullah et al. (2021) & 1 & 1 & 1 & 1 & 1 & $\mathrm{O}$ & O & 1 & 1 & 1 & 1 & 1 & 10 \\
\hline $\begin{array}{l}\text { Palaiodimos et al. } \\
\text { (2021) }\end{array}$ & 1 & 1 & 1 & 1 & 1 & 1 & 1 & O & 1 & 1 & 1 & 1 & 11 \\
\hline Gerwen et al. (2020) & 1 & 1 & 1 & 1 & 1 & $\mathrm{O}$ & 1 & 1 & 1 & 1 & 1 & 1 & 11 \\
\hline You et al. (2020) & 1 & 1 & 1 & 1 & 1 & $\mathrm{O}$ & 1 & 1 & 1 & 1 & 1 & 1 & 11 \\
\hline $\begin{array}{l}\text { Giacomelli et al. } \\
(2021)\end{array}$ & 1 & 1 & 1 & $\mathrm{O}$ & 1 & $\mathrm{O}$ & 1 & 1 & 1 & 1 & 1 & 1 & 10 \\
\hline Sun et al. (2020) & 1 & 1 & 1 & O & 1 & 1 & 1 & 1 & 1 & 1 & 1 & 1 & 11 \\
\hline Pietre et al. (2020) & 1 & 1 & 1 & $\mathrm{O}$ & 1 & 1 & 1 & $\mathrm{O}$ & 1 & 1 & 1 & 1 & 10 \\
\hline Salacup et al. (2020) & 1 & 1 & 1 & 1 & 1 & 1 & 1 & 0 & 1 & 1 & 1 & 1 & 11 \\
\hline Pettit et al. (2020) & 1 & 1 & 1 & $\mathrm{O}$ & $\mathrm{O}$ & 1 & 1 & 1 & 1 & 1 & 1 & 1 & 10 \\
\hline
\end{tabular}

Note: Answer: $1=$ Yes and $0=$ No

Based on the assessment of the quality of the primary articles above, the value of article quality is 10 to 11 . This indicates that the article has good quality for meta-analysis (CEBMa, 2014). 
Table 2. Description of the primary study of the association of obesity with COVID-19 mortality

\begin{tabular}{|c|c|c|c|c|c|c|c|}
\hline $\begin{array}{c}\text { Author } \\
\text { (year) }\end{array}$ & $\begin{array}{c}\text { Countr } \\
y\end{array}$ & $\begin{array}{c}\text { Study } \\
\text { Design }\end{array}$ & $\begin{array}{c}\text { Sampl } \\
\text { e }\end{array}$ & $\begin{array}{c}\mathbf{P} \\
\text { (Population) }\end{array}$ & $\begin{array}{c}\text { I } \\
\text { (Intervention) }\end{array}$ & $\begin{array}{c}\mathrm{C} \\
\text { (Comparison) }\end{array}$ & $\begin{array}{c}\text { O } \\
\text { (Outcome) }\end{array}$ \\
\hline $\begin{array}{l}\text { Giacomell } \\
\text { i et al } \\
\text { (2021) }\end{array}$ & Italy & $\begin{array}{l}\text { Prospec- } \\
\text { tive } \\
\text { Cohort } \\
\text { Study }\end{array}$ & 520 & $\begin{array}{l}\text { Patients with confirmed } \\
\text { COVID19, Median age }=61 \\
(50,72) \text {, Gender: L } 161 \\
(69.1 \%) ; \text { P } 72(30.9 \%)\end{array}$ & $\begin{array}{l}\text { Have comorbidities } \\
\text { Obesity (BMI > 30 } \\
\mathrm{kg} / \mathrm{m} 2), \mathrm{CD} \text {, critical } \\
\text { illness, fever, d-dimer }> \\
\text { 500. LDH }>245\end{array}$ & $\begin{array}{l}\text { No comorbid obesity } \\
\left(\mathrm{BMI}<30 \mathrm{~kg} / \mathrm{m}^{2}\right), \mathrm{CD} \text {, } \\
\text { critical illness, no } \\
\text { fever, d-dimer }<500 \text {, } \\
\text { LDH }<245\end{array}$ & COVID-19 deaths \\
\hline $\begin{array}{l}\text { Ullah et } \\
\text { al. (2021) }\end{array}$ & $\begin{array}{l}\text { Pennsyl } \\
\text { vania }\end{array}$ & $\begin{array}{l}\text { Retro- } \\
\text { spective } \\
\text { Cohort } \\
\text { Study }\end{array}$ & 132 & $\begin{array}{l}\text { Patients with confirmed } \\
\text { COVID-19, Gender }=\mathrm{L} \\
(\mathrm{BMI}<35=88.4 \% ; \mathrm{BMI}>35 \\
=11.6 \%), \mathrm{P}(\mathrm{BMI}<35= \\
67.8 \% ; \mathrm{BMI}>35=32.2 \%)\end{array}$ & $\begin{array}{l}\text { Have comorbid obesity } \\
(\mathrm{BMI}>35 \mathrm{~kg} / \mathrm{m} 2)\end{array}$ & $\begin{array}{l}\text { No comorbid obesity } \\
(\mathrm{BMI}<35 \mathrm{~kg} / \mathrm{m} 2)\end{array}$ & $\begin{array}{l}\text { COVID-19 } \\
\text { deaths, IMV use }\end{array}$ \\
\hline $\begin{array}{l}\text { Hoobs et } \\
\text { al (2021) }\end{array}$ & SEUS & $\begin{array}{l}\text { Retro- } \\
\text { spective } \\
\text { Cohort } \\
\text { Study }\end{array}$ & 502 & $\begin{array}{l}\text { Patients with confirmed } \\
\text { COVID-19, Median age = 62 } \\
(49-71), \text { Gender }=\mathrm{P}(44.8 \%) \\
\text { L }(53.2 \%), \text { Ethnicity }= \\
\text { African American, } \\
\text { Caucasian, Hispanic. }\end{array}$ & $\begin{array}{l}\text { Have comorbid obesity } \\
\text { (BMI > 30 kg/m2), DM, } \\
\text { CD, CKD, stroke, HT, } \\
\text { smoking, liver disease }\end{array}$ & $\begin{array}{l}\text { Does not have } \\
\text { comorbid obesity } \\
\text { (BMI <25 kg/m2), } \\
\text { DM, CD, CKD, Stroke, } \\
\text { HT, liver disease, does } \\
\text { not smoke }\end{array}$ & $\begin{array}{l}\text { Death, severity of } \\
\text { COVID-19 }\end{array}$ \\
\hline $\begin{array}{l}\text { Salacup } \\
\text { et al. } \\
(2020)\end{array}$ & $\begin{array}{l}\text { Pennsyl } \\
\text { vania }\end{array}$ & $\begin{array}{l}\text { Retro- } \\
\text { spective } \\
\text { Cohort } \\
\text { Study }\end{array}$ & 389 & $\begin{array}{l}\text { Patients with confirmed } \\
\text { COVID19, Median age = } 66 \\
(58-76), \text { Gender }=\mathrm{L}(49 \%) \\
\mathrm{P}(51 \%), \mathrm{BMI}=29.39 \pm \\
9.22\end{array}$ & $\mathrm{BMI}>30 \mathrm{~kg} / \mathrm{m} 2$ & BMI normal & $\begin{array}{l}\text { IMV use, COVID- } \\
19 \text { deaths }\end{array}$ \\
\hline $\begin{array}{l}\text { Palaiodim } \\
\text { os et al. } \\
\text { (2020) }\end{array}$ & $\begin{array}{l}\text { New } \\
\text { York }\end{array}$ & $\begin{array}{l}\text { Retro- } \\
\text { spective } \\
\text { Cohort } \\
\text { Study }\end{array}$ & 200 & $\begin{array}{l}\text { Patients with confirmed } \\
\text { COVID-19, Median age = } 64 \\
\text { (50-73.5), Gender = L } \\
(49 \%) \text { P }(51 \%), \text { median } \\
\text { BMI = } 30 \text { (IQR, 26-35) }\end{array}$ & $\begin{array}{l}\text { Have comorbidities } \\
\text { Obesity (BMI > } 35 \mathrm{~kg} / \mathrm{m} 2) \\
\text {, DM, CAD, CKD, COPD, } \\
\text { HT, Asthma, smoking, } \\
\text { alcohol consumption, } \\
\text { intravenous drug use }\end{array}$ & $\begin{array}{l}\text { Does not have } \\
\text { comorbid obesity } \\
\text { (BMI <25 kg/m2), } \\
\text { DM, CAD, CKD, } \\
\text { COPD, HT, Asthma, } \\
\text { does not smoke, does } \\
\text { not consume alcohol, } \\
\text { intravenous drugs }\end{array}$ & $\begin{array}{l}\text { Intubation, need } \\
\text { for oxygenation, } \\
\text { COVID-19 deaths }\end{array}$ \\
\hline $\begin{array}{l}\text { Seiglie et } \\
\text { al }(2020)\end{array}$ & $\begin{array}{l}\text { Massach } \\
\text { uttes }\end{array}$ & $\begin{array}{l}\text { Retro- } \\
\text { spective }\end{array}$ & 450 & $\begin{array}{l}\text { Patients with confirmed } \\
\text { COVID-19, Gender (all BMI }\end{array}$ & $\begin{array}{l}\text { Obesity }(\mathrm{BMI}>30 \mathrm{~kg} / \mathrm{m} 2) \\
\text { Age }>50 \text { years, Hispanic }\end{array}$ & $\begin{array}{l}\text { Not obese }(\mathrm{BMI}<25 \\
\mathrm{kg} / \mathrm{m} 2), \text { Age }<50\end{array}$ & $\begin{array}{l}\text { ICU treatment, } \\
\text { IMV use, COVID- }\end{array}$ \\
\hline
\end{tabular}


Kurniawati et al./ The Effects of Obesity and Type 2 Diabetes Mellitus on Covid-19 Mortality

\begin{tabular}{|c|c|c|c|c|c|c|c|}
\hline & & $\begin{array}{l}\text { Cohort } \\
\text { Study }\end{array}$ & & $=\mathrm{L}(3791) \mathrm{P}(2004)$ & white & $\begin{array}{l}\text { years, Nonhispanic } \\
\text { white }\end{array}$ & 19 deaths \\
\hline $\begin{array}{l}\text { Pietre et } \\
\text { al (2020) }\end{array}$ & Brazil & $\begin{array}{l}\text { Retro- } \\
\text { spective } \\
\text { Cohort } \\
\text { Study }\end{array}$ & 235,555 & $\begin{array}{l}\text { COVID19 confirmed } \\
\text { patient, Age = } 61(\mathrm{IQR}=28) \\
\text { Gender }=\mathrm{L}(43.7 \%) \mathrm{P} \\
(56.3 \%), \text { Ethnicity = white, } \\
\text { black, yellow, brown, red }\end{array}$ & $\begin{array}{l}\text { Having comorbid obesity } \\
\text { treated with symptoms of } \\
\text { dyspnea, oxygen } \\
\text { saturation }<95 \% \text {, distress }\end{array}$ & $\begin{array}{l}\text { Has no comorbid } \\
\text { obesity treated with } \\
\text { symptoms of dyspnea, } \\
\text { oxygen saturation } \\
<95 \% \text {, distress }\end{array}$ & COVID-19 deaths \\
\hline $\begin{array}{l}\text { Gerwen et } \\
\text { al. (2020) }\end{array}$ & $\begin{array}{l}\text { New } \\
\text { York }\end{array}$ & $\begin{array}{l}\text { Retro- } \\
\text { spective } \\
\text { Cohort } \\
\text { Study }\end{array}$ & 3703 & $\begin{array}{l}\text { Patients with confirmed } \\
\text { COVID-19, Median age = } \\
56.8+-18.2, \text { Gender = L } \\
(55.3 \%) \mathrm{P}(44.7 \%)\end{array}$ & $\begin{array}{l}\text { Have comorbid obesity } \\
(\mathrm{BMI}>30 \mathrm{~kg} / \mathrm{m} 2)\end{array}$ & $\begin{array}{l}\text { Has no comorbid } \\
\text { obesity (BMI <25 } \\
\mathrm{kg} / \mathrm{m} 2)\end{array}$ & $\begin{array}{l}\text { IMV use, COVID- } \\
19 \text { deaths }\end{array}$ \\
\hline $\begin{array}{l}\text { Pettit et } \\
\text { al. (2020) }\end{array}$ & Chicago & $\begin{array}{l}\text { Retro- } \\
\text { spective } \\
\text { Cohort } \\
\text { Study }\end{array}$ & 238 & $\begin{array}{l}\text { Patients with confirmed } \\
\text { COVID-19, Age = median : } \\
58.5(17), \text { Gender }=\mathrm{L}(47.5) \\
\mathrm{P}(52.5 \%)\end{array}$ & $\begin{array}{l}\text { Have comorbidities } \\
\text { Obesity (BMI > 30 } \\
\text { kg/m2), HT, DM, CD, } \\
\text { CKD, Cancer, Stroke, } \\
\text { hyperlipidemia }\end{array}$ & $\begin{array}{l}\text { Does not have } \\
\text { comorbid obesity } \\
\left(\mathrm{BMI}<25 \mathrm{~kg} / \mathrm{m}^{2}\right), \mathrm{HT} \text {, } \\
\text { DM, CD, CKD, } \\
\text { Cancer, Stroke, } \\
\text { hyperlipidemia }\end{array}$ & $\begin{array}{l}\text { COVID-19 death, } \\
\text { hypoxemia }\end{array}$ \\
\hline $\begin{array}{l}\text { Czernicho } \\
\text { w et al. } \\
\text { (2020) }\end{array}$ & France & $\begin{array}{l}\text { Prospec- } \\
\text { tive } \\
\text { Cohort } \\
\text { Study }\end{array}$ & 5,795 & $\begin{array}{l}\text { Patients with confirmed } \\
\text { COVID-19, Gender }=(P= \\
2,004 ; \mathrm{L}=3,791)\end{array}$ & $\begin{array}{l}\text { Have comorbidities } \\
\text { Obesity (BMI > 30 } \\
\mathrm{kg} / \mathrm{m} 2 \text { ), diabetes, HT, } \\
\text { dyslipidemia, sleep apnea, } \\
\text { CKD, HF, Cancer, Smoker }\end{array}$ & $\begin{array}{l}\text { No comorbidities } \\
\text { Obesity (BMI > 30 } \\
\text { kg/m2), diabetes, HT, } \\
\text { dyslipidemia, sleep } \\
\text { apnea, CKD, HF, } \\
\text { Cancer, Smoker }\end{array}$ & COVID-19 deaths \\
\hline
\end{tabular}


Kurniawati et al./ The Effects of Obesity and Type 2 Diabetes Mellitus on Covid-19 Mortality

\section{Results of the relationship between obesity and covid-19 death}

\section{a. Forest Plot}

Interpretation of the results of the metaanalysis process can be seen through the forest plot. Figure 3 show that obesity increases mortality in COVID-19 patients. Meta-analysis results show obesity increases the incidence of death in COVID19 patients 1.50 times compared to nonobese $(\mathrm{aOR}=1.50 ; 95 \% \mathrm{CI}=1.17$ to $1.93 ; \mathrm{p}=$ o.001). The heterogeneity of the research data shows $\mathrm{I}^{2}=83 \%$ so that the distribution of the data is declared heterogeneous (random effect model).

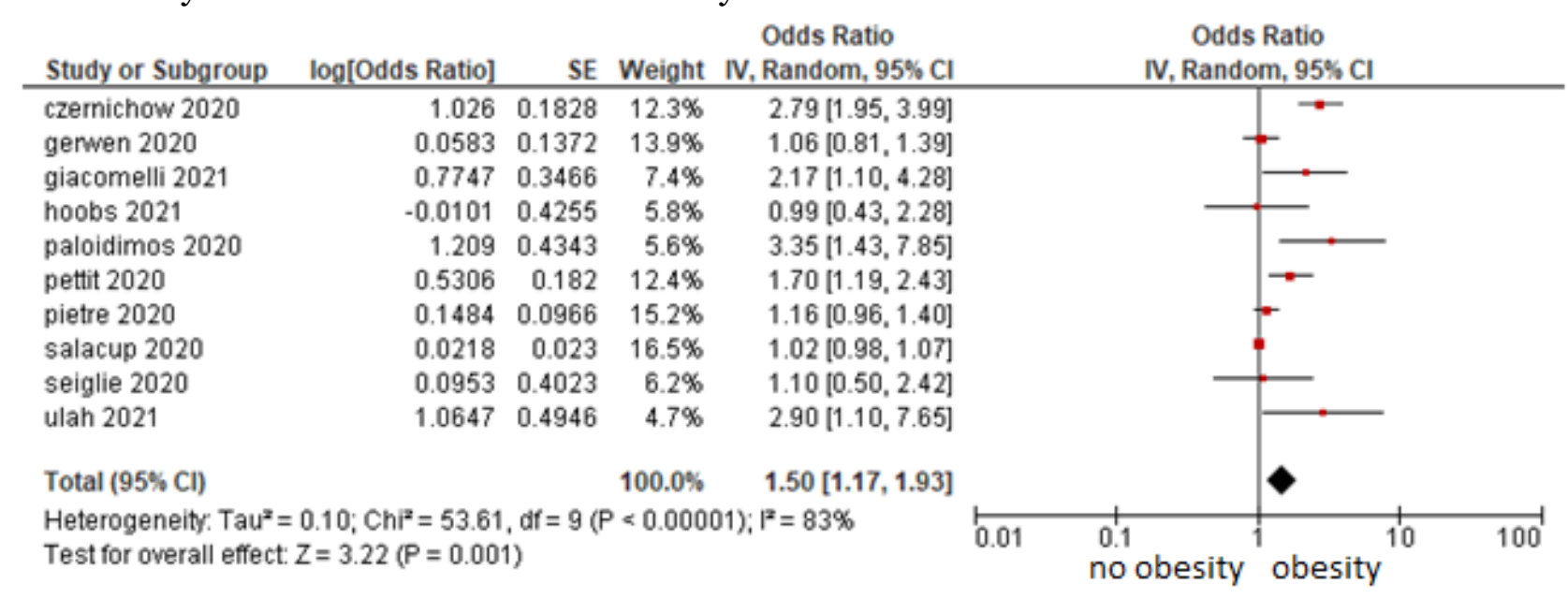

Figure 3. Forest plots the relationship between obesity and COVID-19 mortality

\section{b. Funnel Plot}

Based on Figure 4, the funnel plot of obesity with COVID-19 mortality, shows an asymmetric distribution of primary study esti-

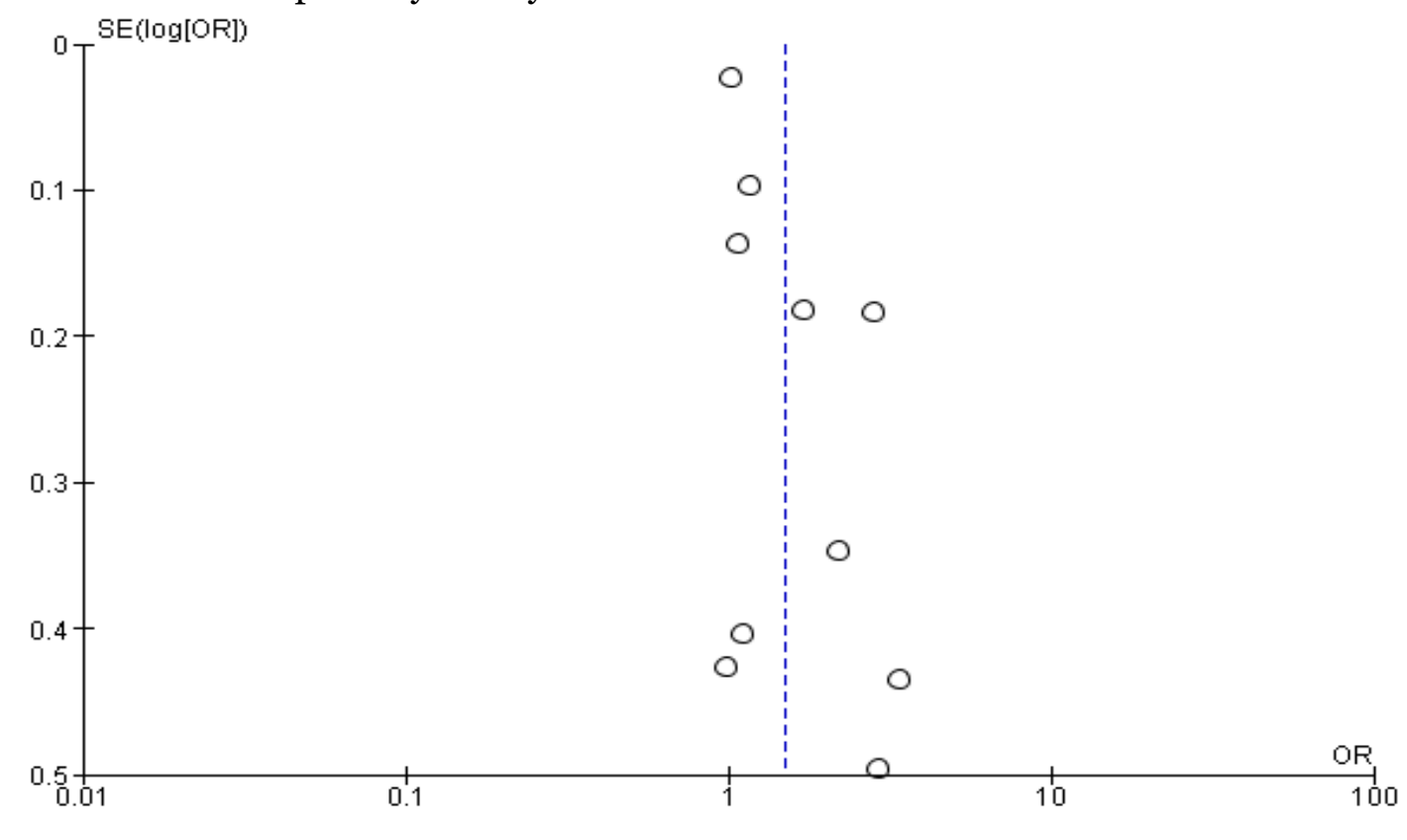

Figure 4. Funnel plot of obesity with COVID19 mortality mates that are more to the right of the vertical line than to the left of the vertical line, which indicates that there is publication bias that overestimates the effect. 
Table 3. Description of the primary study of the association of T2DM with COVID-19 mortality

\begin{tabular}{|c|c|c|c|c|c|c|c|}
\hline Research & Country & Study Design & Sample & P (Population) & I (Intervention) & C (Comparison) & O (Outcome) \\
\hline Id et al (2021) & Ethiopia & $\begin{array}{l}\text { Retrospective } \\
\text { Cohort Study }\end{array}$ & 429 & $\begin{array}{l}\text { Patients with confirmed COVID- } \\
19, \text { Age <50 years (6o.8\%), male } \\
(64.1 \%) \text {, had comorbidities } \\
(43.8 \%)=\text { T2DM }(19.8 \%) \text { HT } \\
(25.2 \%), \text { Asthma }(6.1 \%), \text { CD } \\
(5.6 \%))\end{array}$ & $\begin{array}{l}\text { Having comorbid } \\
\text { T2DM, } \mathrm{n}=344 \\
(80.2 \%)\end{array}$ & $\begin{array}{l}\text { No comorbid T2DM, } \\
\mathrm{n}=85(19.8 \%)\end{array}$ & $\begin{array}{l}\text { Severity, death } \\
\text { of COVID-19 }\end{array}$ \\
\hline $\begin{array}{l}\text { Sun et al. } \\
(2020)\end{array}$ & China & $\begin{array}{l}\text { Retrospective } \\
\text { Cohort Study }\end{array}$ & 3400 & $\begin{array}{l}\text { COVID-19 confirmed patient, } \\
\text { Age }>65 \text { years old }\end{array}$ & $\begin{array}{l}\text { Have comorbidities of } \\
\text { DMT2, HT, HT+DM }\end{array}$ & $\begin{array}{l}\text { Does not have } \\
\text { comorbidities of } \\
\text { DMT2, HT, HT+DM }\end{array}$ & $\begin{array}{l}\text { COVID-19 } \\
\text { deaths }\end{array}$ \\
\hline $\begin{array}{l}\text { Seiglie et al } \\
(2020)\end{array}$ & $\begin{array}{l}\text { Massachut } \\
\text { tes }\end{array}$ & $\begin{array}{l}\text { Retrospective } \\
\text { Cohort Study }\end{array}$ & 450 & $\begin{array}{l}\text { Patients with confirmed } \\
\text { COVID19, Age mean SD = T2DM } \\
61.1 \text { vs NT2DM 66.7, Gender = L } \\
\text { (T2DM 54.8; NT2DM 61.8) vs P } \\
\text { (T2DM 45.2; NT2DM 38.2, Race } \\
\text { = White, Hispanic, African } \\
\text { American }\end{array}$ & $\begin{array}{l}\text { Have comorbid DMT2 } \\
\text { (HbA1c } 8.1 \%), \mathrm{BMI}= \\
\text { overweight } 25-29 \\
\mathrm{~kg} / \mathrm{m} 2(105), \text { obese } \\
>30 \mathrm{~kg} / \mathrm{m} 2(100)\end{array}$ & $\begin{array}{l}\text { No comorbidities } \\
\text { with T2DM, (HbA1c - } \\
\text { ), BMI = overweight } \\
25-29 \mathrm{~kg} / \mathrm{m} 2 \text { (105), } \\
\text { obese }>30 \mathrm{~kg} / \mathrm{m} 2 \\
\text { (91) }\end{array}$ & $\begin{array}{l}\text { ICU treatment, } \\
\text { IMV use, } \\
\text { COVID-19 } \\
\text { deaths }\end{array}$ \\
\hline $\begin{array}{l}\text { Barron et al. } \\
(2020)\end{array}$ & The UK & $\begin{array}{l}\text { Retrospective } \\
\text { Cohort Study }\end{array}$ & $\begin{array}{l}61,414,4 \\
70\end{array}$ & $\begin{array}{l}\text { Patients with confirmed } \\
\text { COVID19, Age = 0-> 80 years, } \\
\text { Ethnicity = Asian, black, white }\end{array}$ & $\begin{array}{l}\text { Have comorbidities of } \\
\text { DMT1, T2DM, other } \\
\text { types of DM }\end{array}$ & No comorbid DM & $\begin{array}{l}\text { COVID-19 } \\
\text { deaths }\end{array}$ \\
\hline $\begin{array}{l}\text { You et al. } \\
(2020)\end{array}$ & Korea & $\begin{array}{l}\text { Retrospective } \\
\text { Cohort Study }\end{array}$ & 5473 & $\begin{array}{l}\text { Patients with confirmed } \\
\text { COVID19, Gender = P (55.4\%) L } \\
(44.6 \%)\end{array}$ & $\begin{array}{l}\text { Have comorbid } \\
\text { DMT2, n =56, use } \\
\text { antibiotics, oxygen } \\
\text { therapy, ventilator, } \\
\text { antiviral and } \\
\text { antipyretic }\end{array}$ & $\begin{array}{l}\text { Did not have } \\
\text { comorbid DMT2, } \mathrm{n}= \\
\text { 28, did not use } \\
\text { antibiotics, oxygen } \\
\text { therapy, ventilator, } \\
\text { antiviral and } \\
\text { antipyretic }\end{array}$ & $\begin{array}{l}\text { ICU care, } \\
\text { COVID-19 death }\end{array}$ \\
\hline $\begin{array}{l}\text { Satman et al. } \\
(2021)\end{array}$ & Turkey & $\begin{array}{l}\text { Retrospective } \\
\text { Cohort Study }\end{array}$ & 93571 & $\begin{array}{l}\text { Age }(\mathrm{IQR})=\mathrm{T} 2 \mathrm{DM}(2 \mathrm{O}) \text { non-DM } \\
(22), \text { Gender = L T2DM }(42.3 \%) \\
\text { non-DM }(55 \%)\end{array}$ & $\begin{array}{l}\text { Have comorbid T2DM } \\
(\text { HbA1c }>7 \%)\end{array}$ & $\begin{array}{l}\text { No comorbid T2DM } \\
(\mathrm{HbA} 1 \mathrm{c}<7 \%)\end{array}$ & $\begin{array}{l}\text { Hospital } \\
\text { admission, } \\
\text { COVID-19 death }\end{array}$ \\
\hline
\end{tabular}


Kurniawati et al./ The Effects of Obesity and Type 2 Diabetes Mellitus on Covid-19 Mortality

2. Results of the relationship between T2DM and Covid-19 deaths

\section{a. Forest Plot}

Interpretation of the results of the metaanalysis process can be seen through the forest plot. Figure 5 shows that T2DM increases mortality in COVID-19 patients. The results of the meta-analysis of cohort studies showed that T2DM increased the incidence of death in COVID-19 patients by 1.93 times compared to those without T2DM $(\mathrm{aOR}=1.93 ; 95 \% \mathrm{CI}=1.28$ to 2.90 ; $\mathrm{p}=0.002)$. The heterogeneity of the research data shows $\mathrm{I}^{2}=99 \%$ so that the distribution of the data is said to be heterogeneous (random effect model).

\section{Odds Ratio Odds Ratio}

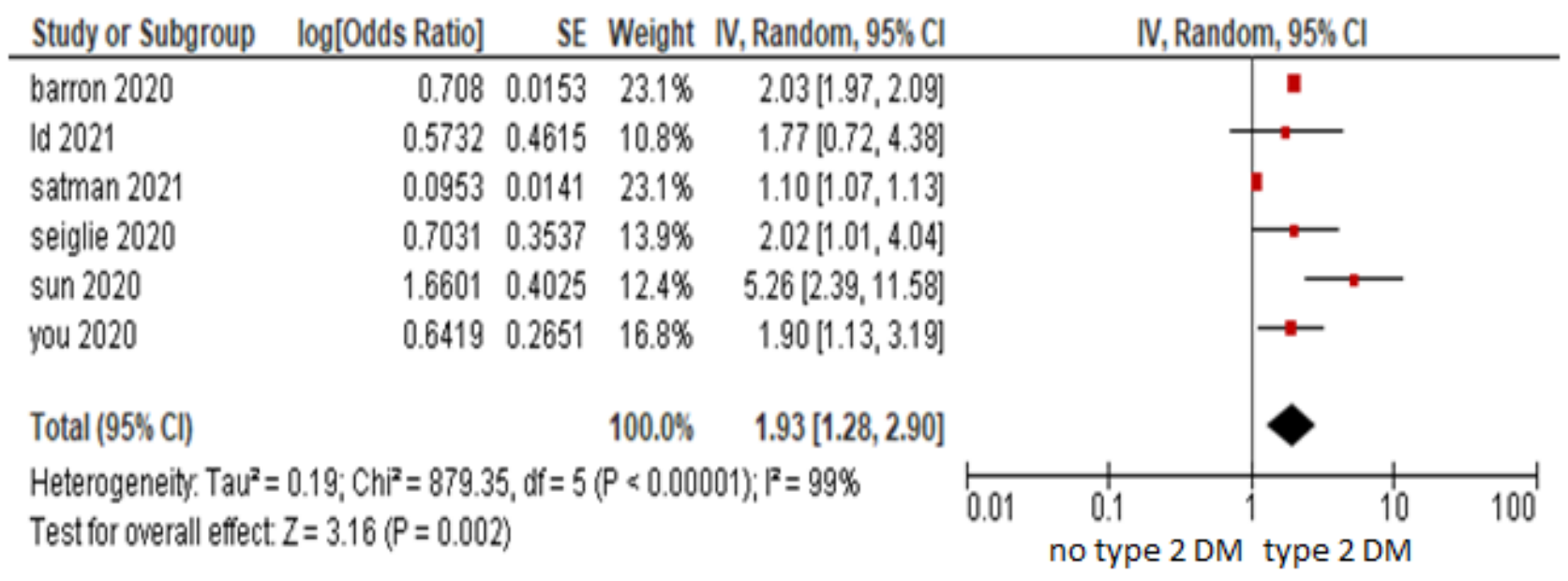

Figure 5. Forest plot of the relationship between DMT2 and COVID-19 mortality

\section{b. Funnel Plot}

Figure 6 funnel plot of DMT2 with COVID19 mortality shows a fairly symmetrical

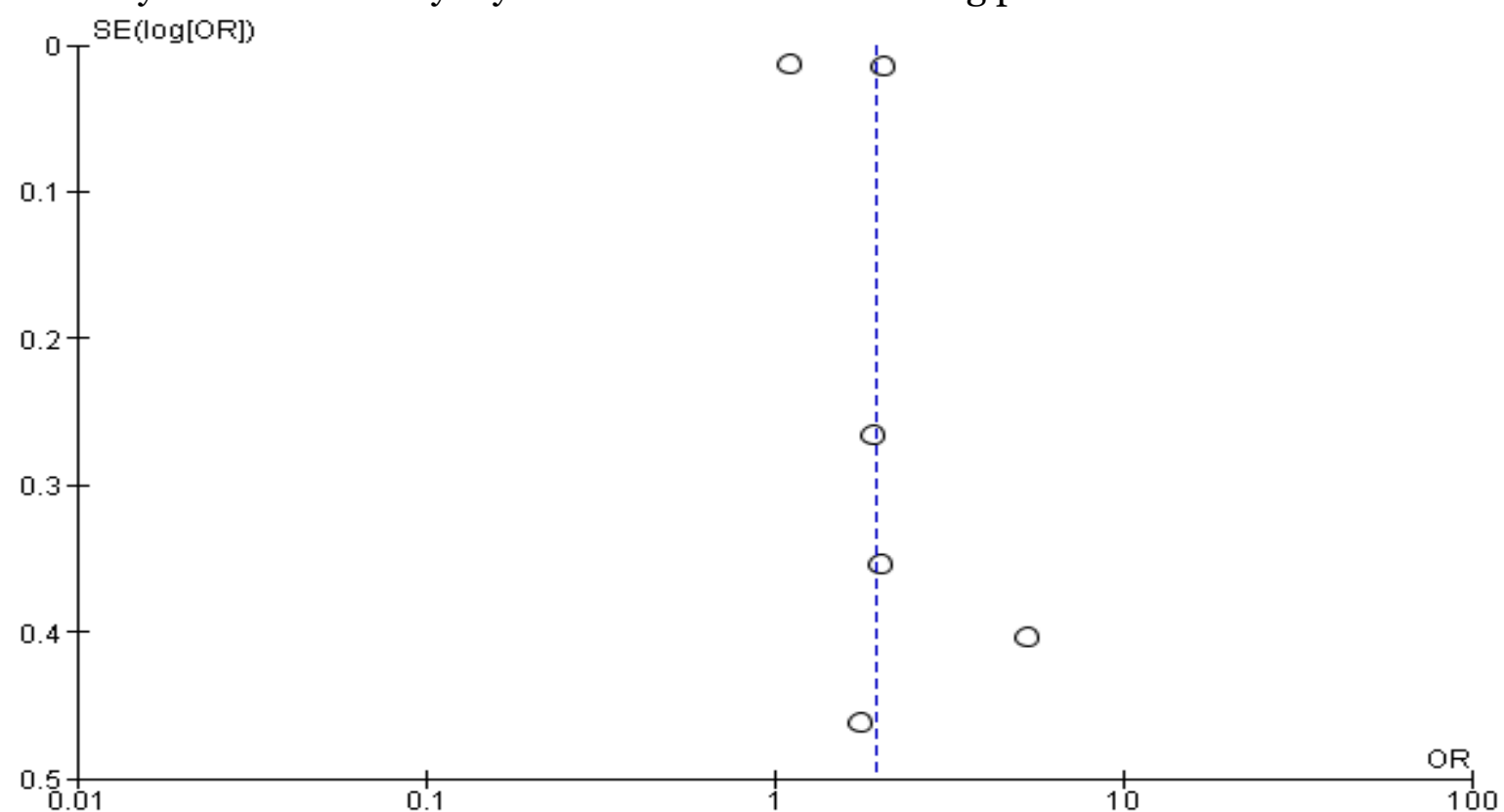

distribution of primary study estimates to the left and right of the vertical line, not indicating publication bias.

Figure 6. Funnel plot DMT2 with COVID-19 deaths 


\section{DISCUSSION}

This systematic review and meta-analysis research raised the theme of the effect of comorbid obesity and T2DM on mortality from COVID19. The dependent variable analyzed was COVID19 mortality. This meta-analysis study uses research sources that control confounding factors or confounding factors that can be seen from the inclusion requirements of the study, namely multivariate analysis and the statistical results reported are adjusted odds ratio (aOR). The combined results of the relationship between obesity and T2DM with COVID-19 mortality were processed using the RevMan 5.3 application, while the results of a systematic study and metaanalysis were presented in the forest plots and funnel plots.

\section{The relationship of obesity and COVID-19 mortality}

The results of the forest plot of research articles with an observational cohort design showed that obesity was 1.50 times the risk of dying from COVID-19 compared to without obesity $(\mathrm{aOR}=1.5 \mathrm{O} ; 95 \% \mathrm{CI}=1.17$ to 1.93; $\mathrm{p}=0.001)$.

Obesity plays an important role in the pathogenesis of COVID-19 infection. In fact, the immune system, which is a key player in the pathogenesis of COVID 19, also plays an important role in inflammation-induced adipose tissue. This inflamamation of adipose tissue results in metabolic dysfunction that has the potential to cause dyslipidemia, insulin resistance, type 2 diabetes mellitus, hypertension, and cardiovascular disease (Kassir, 2020).

This is supported by the study of Nakeshbandi et al. (2020), that overweight and obese patients who have COVID-19 are at increased risk for death and intubation compared to those with a normal BMI. After controlling for age, gender, diabetes, hypertension, and qSOFA scores, there was a significant increase in the risk of death in the overweight $(\mathrm{RR}=1.4 ; 95 \% \mathrm{CI}=1.1$ to 1.9) and obese ( $\mathrm{RR}=1.3$; $95 \% \mathrm{CI}=1.1$ to 1.7$)$ compared with those with a normal BMI.

The Cunningham et al (2020) study revealed that comorbid obesity $(\mathrm{aOR}=2.30$; 95\% CI; 1.77-2.98; vs no obesity; $\mathrm{p}<0.001$ ) was associated with a greater risk of death or mechanical ventilation. The odds of death or mechanical ventilation did not differ significantly by race and ethnicity. Comorbid obesity was present in 140 patients (41\%) who died or required ventilation.

In addition, the study of Hendren et al (2020) revealed that obese patients were more likely to be hospitalized with COVID19 , and were at higher risk of dying in hospital or on mechanical ventilation, particularly if they were young (aged 50 years). Class III obesity was associated with a higher risk of in-hospital death ( $\mathrm{HR}=$ $1.26 ; 95 \% \mathrm{CI}=1.00$ to 1.58 ). Severe obesity (BMI $40 \mathrm{~kg} / \mathrm{m}^{2}$ ) was associated with an increased risk of in-hospital death only at 50 years $(\mathrm{HR}=1.36 ; 95 \% \mathrm{CI}=1.01$ to 1.84$)$.

Yang et al (2020) in their study explained that compared to non-obese patients, obese patients had a significantly increased risk of infection ( $\mathrm{OR}=3.19$; 95\% $\left.\mathrm{CI}=1.45-7.03 ; \mathrm{I}^{2}=98 \%\right)$, hospitalization $\left(\mathrm{OR}=1.77\right.$; CI $95 \% ; 1.61$ to $\left.1.95 ; \mathrm{I}^{2}=43 \%\right)$, severe clinical disease $(\mathrm{OR}=2.88 ; 95 \% \mathrm{CI}$ : 1.99-4.16; $\left.\mathrm{I}^{2}=49.9 \%\right)$, mechanical ventilation $\left(\mathrm{OR}=1.66 ; 95 \% \mathrm{CI}=1.42\right.$ to $1.94 ; \mathrm{I}^{2}=$ $41.3 \%$, intensive care unit (ICU) $(\mathrm{OR}=2.06$; $\left.95 \% \mathrm{CI}=1.49-2.85 ; \mathrm{I}^{2}=71.4 \%\right)$ and mortality $\left(\mathrm{OR}=1.48 ; 95 \% \mathrm{CI}=1.18\right.$ to $1.85 ; \mathrm{I}^{2}=$ 80.8\%). Patients with obesity may have a 1.48 times greater risk of developing severe COVID-19 and dying.

\section{The relationship between DMT2 and COVID-19 mortality}

The results of the forest plot of research articles with an observational design 
showed that T2DM had a 1.93 times risk of dying from COVID-19 compared to those without T2DM and the results were statistically significant (aOR=1.93; 95\% CI= 1.28 to $2.90 ; \mathrm{p}=0.002$ ).

Patients with T2DM have a background of increased levels of inflammation associated with obesity and insulin resistance in addition to other comorbidities including hypertension, obesity, cardiovascular disease, dyslipidemia, and advanced age. T2DM with hyperglycemia is one of the factors leading to increased expression of angiotensin converting enzyme 2 (ACE2) in the lungs and other tissues; ACE2 is the cellular "receptor" and the entry site for viruses. Pre-existing chronic inflammation with an increased inflammatory response to infection and increased viral load causes an extreme systemic immune response (cytokine storm) that is strongly associated with increased severity of COVID-19 (Bloomgarden, 2020).

This is supported by Sonmez (2021), T2DM patients $(n=9213)$ were compared with a group without diabetes $(n=9213)$ which were matched using propensity scores for age and sex. Compared with the group without T2DM, 30-day mortality after hospitalization was higher in patients with T2DM (13.6\% vs $8.7 \%$; HR $=1.75 ; 95 \%$ CI: $1.58-1.93 ; \mathrm{p}<0.001)$. It was concluded that patients with T2DM who were hospitalized due to COVID-19 were at increased risk of death, length of hospital stay, and ICU admission.

The study (Holman et al., 2020a) conducted in the UK on 16 February and 11 May 2020, among 264,390 people with type 1 diabetes and 2,874,020 people with type diabetes 21,604 people with type 1 diabetes and 36,291 people with type 2 diabetes died from all causes. Compared with people with an HbA1c of 48-53 $\mathrm{mmol} / \mathrm{mol}$ (6.5-7.0\%), people with an
HbA1c of $86 \mathrm{mmol} / \mathrm{mol}$ (10\%) or higher had increased COVID-19-related deaths $(\mathrm{HR}=2.23 ; 95 \% \mathrm{CI}=1.50-3.30, \mathrm{p}<0.001)$ in type 1 diabetes and $(\mathrm{HR}=1.61 ; 95 \% \mathrm{CI}=$ 1.47 to 1.77 ; $\mathrm{p}<0.001$ ) in type 2 diabetes.

Rastad et al. (2020) in his study revealed that COVID19 patients with DM had a 1.69 times greater increase in mortality, besides that the lymphocyte count, creatinine and CRP concentration could be considered as significant predictors of COVID-19 mortality in these patients.

Huang et al. (2020) mention that DM is associated with mortality, severe COVID19, ARDS, and disease progression in patients with COVID-19. Meta-analysis showed that DM was associated with a composite adverse outcome $(\mathrm{RR}=2.38$; 95\% CI: 1.88 3.03; $\left.\mathrm{p}<0.001 ; \mathrm{I}^{2}=62 \%\right)$ and its subgroup consisting of death $(\mathrm{RR}=2.38$; 95\% CI: 1.44 to 3.11 ; $<$ <.001; $\mathrm{I}^{2}=72 \%$ ), severe COVID$19(\mathrm{RR}=2.45 ; 95 \% \mathrm{CI}=1.79$ to $3.35 ; \mathrm{p}<$ 0.001; $\left.\mathrm{I}^{2}=45 \%\right)$, ARDS $(\mathrm{RR}=4.64 ; 95 \% \mathrm{CI}=$ 1.86 to $\left.11.58 ; \mathrm{p}<0.001 ; \mathrm{I}^{2}=9 \%\right)$, and disease progression $(\mathrm{RR}=3.31 ; 95 \% \mathrm{CI}=1.08$ to 10.14; $\left.\mathrm{p}=0.04 ; \mathrm{I}^{2}=0 \%\right)$.

The limitation of this study is that there is a publication bias that is shown in the funnel plot of the cohort study on the obesity variable. There is a language bias, because in this study the selected articles were only published in English, thus ignoring articles in other languages.

\section{AUTHOR CONTRIBUTION}

Oktaviana Kurniawati is the main researcher who chooses the topic, searches and collects research data. Hanung Prasetya and Bhisma Murti played a role in analyzing data and reviewing research documents.

\section{FUNDING AND SPONSORSHIP}

This study is self-funded. 
Kurniawati et al./ The Effects of Obesity and Type 2 Diabetes Mellitus on Covid-19 Mortality

\section{CONFLICT OF INTEREST}

There is no conflict of interest in this study.

\section{ACKNOWLEDGEMENT}

We are very grateful to the database providers PubMed, Google Scholar, JAMA, Willey and Science Direct.

\section{REFERENCES}

Abaci A, Oguzhan A, Kahraman S, Eryol NK, Ünal S (1999). Effect of Diabetes Mellitus on Formation of. Am Health Assoc J. 99(17): 2239-2242. https://doi.org/10.1161/01.CIR.99.17.2239.

AHA (2014). Body mass index in adult. American Health Association Journal.

Aigner A, Grittner U, Rolfs A, Norrving B, Siegerink B, Busch MA (2017). Contribution of established stroke risk factors to the burden of stroke in young adults. AHA Journal. 48: 1-9. https://doi.org/10.1161/STROKEAHA.117.0 16599.

Al-Benna S (2020). Association of high level gene expression of ACE2 in adipose tissue with mortality of COVID19 infection in obese patients. Obes Med. 19: 100283. https://doi.org/10.1016/j.obmed.2020.100283.

Barron E, Bakhai C, Kar P, Weaver A, Bradley D, Ismail H, Knighton $\mathrm{P}$, et al. (2020). Associations of type 1 and type 2 diabetes with COVID-19related mortality in England: a wholepopulation study. The Lancet Diabetes Endocrinol. 8(10): 813-822. https://doi.org/10.1016/S2213-8587(20)30272-2

Bloomgarden ZT (2020). Diabetes and COVID-19. J Diabetes. 12(4): 347348. https://doi.org/10.1111/1753-0407.13027.

Chen G, Wu D, Guo W, Cao Y, Huang D, Wang H, Wang $\mathrm{T}$, et al. (2020). Clinical and immunological features of severe and moderate coronavirus disease 2019. J Clin Invest. 130(5): 2620-2629. https://doi.org/10.1172/JCI137244.

Czernichow S, Beeker N, Rives-Lange C, Guerot E, Diehl JL, Katsahian S, Hulot JS, et al. (2020). Obesity doubles mortality in patients hospitalized for severe acute respiratory syndrome coronavirus 2 in Paris Hospitals, France: A cohort study on 5,795 patients. Obesity (Silver Spring). 28 (12): 2282-2289. https://doi.org/10.1002/oby.23014.

Lima CMAO (2020). Information about the new coronavirus disease (COVID-19). Radiol Bras. 53(2): v-vi. https://doi.org/10.1590/0100-3984.2020.53.2e1.

Diaz JH (2021). Hypothesis: Angiotensinconverting enzyme inhibitors and angiotensin receptor blockers may increase the risk of severe COVID-19. J Travel Med. 27(3): 1-7. https://doi.org/10.1093/JTM/TAAA041.

Dixon JB (2010). The effect of obesity on health outcomes. Mol Cell Endocrinol. 316(2): 104-108. https://doi.org/10.1016/j.mce.2009.07.008.

Flack JM, Ferdinand KC, Nasser SA (2003). Epidemiology of hypertension and cardiovascular disease in African Americans. J Clin Hypertens (Greenwich). 5(1): 5-11. https://doi.org/10.1111/j.1524-6175.2003.02152.x.

Gerwen MV, Alsen M, Little C, Barlow, J., Genden E, Naymagon L, Tremblay, D (2021.). Risk factors and outcomes of COVID- 19 in New York City: A retrospective cohort study. J Med Virol. 93(2): 907-915. https://doi.org/10.1002/jmv.26337.

Giacomelli A, De Falco T, Oreni L, Pedroli A, Ridolfo AL, Calabrò E, Carrozzo G et al. (2021). Impact of gender on patients hospitalized for SARS- COV- 
Kurniawati et al./ The Effects of Obesity and Type 2 Diabetes Mellitus on Covid-19 Mortality

2 infection: A prospective observational study. J Med Virol. 93(7): 45974602. https://doi.org/10.1002/jmv.26933.

Guan W, Ni Z, Hu Y, Liang W, Ou C, He J, Liu L, et al. (2020). Clinical characteristics of Coronavirus disease 2019 in China. N Engl J Med. 382(18): 17081720. https://doi.org/10.1056/nejmoa2002032.

Hamzah FAB, Lau CH, Nazri H, Ligot DC, Lee G, Tan CL, Shaib MKBM et al. (2020). Corona Tracker: World-wide Covid-19 outbreak data analysis and prediction. Bulletin of the World Health Organization, March, Submitted.

Holman N, Knighton P, Kar P, O'Keefe J, Curley M, Weaver A, Barron E, et al. (2020). Risk factors for COVID-19related mortality in people with type 1 and type 2 diabetes in England: a population-based cohort study. Lancet Diabetes Endo. 8(10): 823833. https://doi.org/10.1016/S22138587(20)30271-0.

Holman N, Knighton P, Kar P, O’Keefe J, Curley M, Weaver A, Barron E, et al. (2020). Type 1 and type 2 diabetes and COVID-19 related mortality in England: A cohort study in people with diabetes. SSRN Electronic Journal. https://doi.org/10.2139/ssrn.3605226.

Huang I, Lim MA, Pranata R (2020). Diabetes mellitus is associated with increased mortality and severity of disease in COVID-19 pneumonia - A systematic review, meta-analysis, and meta-regression. Diabetes Metab Syndr. 14(4): 395-403. https://dx.doi.org/10.1016\%2Fj.dsx.2020.04.01

8.

Id TWL, Hassen IS, Ayele BT, Tsegay YG, Abebe S, Edo MG, Maru EH, et al.
(2021). Laboratory biomarkers of COVID-19 disease severity and outcome: Findings from a developing country. PLoS One. 16(3): eo246087. https://doi.org/10.1371/journal.pone. 0246087.

Jannah PI, Pamungkasari EP, Prasetya H (2021). The effect of sleep duration on overweight or obesity in female adolescents: A meta-analysis study. Indones J Med. 6(1): 52-61. https://doi.o$\mathrm{rg} /$ 10.26911/theijmed.2021.06.01.06.

Jayawardena R, Jeyakumar DT, Misra A, Hills AP, Ranasinghe P (2020). Obesity: A potential risk factor for infection and mortality in the current COVID-19 epidemic. Diabetes Metabolic Synd. 14(6): 2199-2203. https://doi.org/10.1016/j.dsx.2020.11.001.

Kassir R (2020). Risk of COVID-19 for patients with obesity. Obes Rev. 21(6): 10-11. https://doi.org/10.1111/obr.13034.

Weston S, Frieman MB (2020). COVID-19: Knowns, unknowns, and questions. mSphere. 5(2): e00203-20. https://doi.org/10.1128/msphere.00203-20.

Kruger HS, Puoane T, Senekal M, van Der MM (2005). Obesity in South Africa: challenges for government and health professionals. Public Health Nutr. 8 (5): 491-500. https://doi.org/10.1079/PHN2OO5785.

Kumar A, Arora A, Sharma P, Anil S (2020). Is diabetes mellitus associated with mortality and severity of COVID-19? A meta-analysis. Diabetes Metab Syndr: Clin Res Rev. 14(4): 535-545. https://doi.org/10.1016/j.dsx.2020.04.044.

Moreno L, Mesana M, Gonza'lez-Gross M, Gil CM, Ortega FB, Fleta J, Wärnberg $\mathrm{J}$, et al. (2008). Body fat distribution reference standards in Spanish adolescents: The AVENA Body fat distri- 
Kurniawati et al./ The Effects of Obesity and Type 2 Diabetes Mellitus on Covid-19 Mortality

bution reference standards in Spanish adolescents: the AVENA Study. Int J Obes (Lond). 31(12): 1798-805. https://doi.org/10.1038/sj.ijo.08036

70 .

Nakeshbandi M, Maini R, Daniel P, Rosengarten $\mathrm{S}$, Parmar $\mathrm{P}$, Wilson $\mathrm{C}$, Kim JM, et al. (2020). The impact of obesity on COVID-19 complications: a retrospective cohort study. Int J Obes. 44(9): 1832-1837. https://doi.org/10.1038/s41366-020-0648-x.

Nasraway Jr SA, Albert M, Donnelly A M, Ruthazer R, Shikora SA, Saltzman E (2006). Morbid obesity is an independent determinant of death among surgical critically ill patients. Crit Care Med. 34(4): 964-70. https://doi.org/10.1097/01.CCM.0000205758.18891. 70.

Palaiodimos L, Kokkinidis DG, Li W, Karamanis D, Ognibene J, Arora S, Southern WN, Mantzoros CS (2020). Severe obesity is associated with higher inhospital mortality in a cohort of patients with COVID-19 in the Bronx, New York. Metabolism. 108: 154262. https://doi.org/10.1016/j.metabol.20 20.154262.

Pangestu U, Lanti Y, Dewi R, Prasetya H (2021). The effect of ear acupuncture in reducing body weight in obesity patients: A meta-analysis. Indones $\mathrm{J}$ Med. 06(01): 23-31.

Pettit NN, MacKenzie EL, Ridgway JP, Pursell K, Ash D, Patel B, Pho MT (2020). Obesity is associated with increased risk for mortality among hospitalized patients with COVID-19. Obesity. 28(10): 1806-1810. https://doi.org/10.1002/oby.22941.

Prasiska DI (2014). Analisis faktor risiko berat badan lahir pada kematian perinatal menggunakan meta analysis. Jurnal Biometrika Kependuduk- an. 3(1): 28-33.

Rajpal A, Rahimi L, Ismail-Beigi F (2020). Factors leading to high morbidity and mortality of COVID-19 in patients with type 2 diabetes. J Diabet. 12(12): 895-908. https://doi.org/10.1111/1753-0407.13085.

Sacco RL, Kasner SE, Broderick JP, Caplan LR, Connors JJB, Culebras A, Elkind MSV, et al. (2013). AHA / ASA expert consensus document an updated definition of stroke for the 21st century. Am Health Assoc J. 44(7): 20642089. https://doi.org/10.1161/STR.obo13e318296aeca.

Satman I, Demirci I, Haymana C, Tasci I, Salman S, Ata N, Dagdelen S, et al. (2021). Unexpectedly lower mortality rates in COVID-19 patients with and without type 2 diabetes in Istanbul. Diabet Res Clin Prac. 174: 108753. https://doi.org/10.1016/j.diabres.202 1.108753 .

Seiglie J, Platt J, Cromer SJ, Bunda B, Foulkes AS, Bassett IV, Hsu J, Meigs JB (2020). Diabetes as a risk factor for poor early outcomes in patients hospitalized with COVID-19. 43(12): 2938-2944. https://doi.org/10.2337/dc20-1506.

Setiati S, Azwar MK (2020). COVID-19 and Indonesia. Acta Med Indones. 52(1): 84-89.

Shi Q, Zhang X, Jiang F, Zhang X, Hu N, Bimu C, Feng J, et al. (2020). Clinical characteristics and risk factors for mortality of COVID-19 patients with diabetes in Wuhan, China: A twocenter, retrospective study. Diabet Care. 43(7): 1382-1391. https://doi.org/10.2337/dc20-0598.

Soetjipto HP (1955). Aplikasi meta-analisis dalam pengujian validitas aitem (Vol. 2). Buletin Psikologi. 3(2). https://doi.org/10.22146/bpsi.13392. 
Sonmez A (2021). Clinical characteristics and outcomes of COVID-19 in patients with type 2 diabetes in Turkey: A nationwide study (TurCoviDia). J Diabetes. 13(7): 585-595. https://doi.org/10.1111/1753-0407.13171.

Ssentongo P, Sentongo AE, Heilbrunn ES, Ba DM, Chinchilli VM (2020). Association of cardiovascular disease and 10 other pre-existing comorbidities with COVID-19 mortality: A systematic review and meta-analysis. PLoS ONE. 15(8): 1-16. https://doi.org/10.1371/journal.pone.0238215.

Suresh S, Siddiqui M, Abu M, Jou J, Simmer S, Mendiratta V, Russell S, et al. (2021). Obesity research \& clinical practice association of obesity with illness severity in hospitalized patients with COVID-19: A retrospective cohort study. Obesity Res Clin Prac. 15(2): 172-176. https://doi.org/10.1016/j.orcp.2021.02.006.

Susilo A, Rumende CM, Pitoyo CW, Santoso WD, Yulianti M, Herikurniawan H, Sinto R, et al. (2020). Coronavirus disease 2019: Tinjauan literatur terkini. Jurnal Penyakit Dalam Indonesia. 7(1): 45. https://doi.org/10.7454/jpdi.v7i1.415.

Ullah W, Roomi S, Nadeem N, Saeed R, Tariq S, Ellithi M (2021). Impact of body mass index on COVID-19related in- hospital outcomes and mortality. J Clin Med Res. 13(4): 230-236. https://doi.org/10.14740/jocmr4239.

Wang X, Liu Z, Li J, Zhang J, Tian S, Lu S,
Qi M, Ma J, Qiu B, Dong W, Xu Y (2020). Impacts of Type 2 diabetes on disease severity, therapeutic effect, and mortality of patients with COVID-19. J Clin Endocrinol Metab. 105(12): 1-11. https://doi.org/10.121o/clinem/dgaa535.

WHO (2007). National Diabetes Fact Sheet, 2007.

WHO (2016). Global report on diabetes.

WHO (2018). Fact sheets obesity and overweight. WHO.

WHO (2019). Key fact. WHO.

Widhiastuti H (2002). Studi meta-analisis tentang hubungan (meta-Analysis study on relationship). Jurnal Psikologi. 1: 28-42.

You JH, Lee SA, Chun S, Song SO, Lee B, Kim DJ (2020). Original article clinical outcomes of COVID-19 patients with type 2 diabetes: A populationbased study in Korea. 901-908.

Zhao R, Sun Y, Zhang Y, Wang W, Wang S, Wang C, Liu J, Gao L, Hu Z, Fei J, Hou X, Zheng H, Chen L (2020). Distinguishable immunologic characteristics of COVID-19 patients with comorbid type 2 diabetes compared with nondiabetic individuals. Mediators of Inflammation. https://doi.org/10.1155/2020/6914878.

Zhu L, She ZG, Cheng X, Qin JJ, Zhang XJ, Cai J, Lei F, et al. (2020). Association of blood glucose control and outcomes in patients with COVID-19 and pre-existing type 2 diabetes. Cell Metab. 31(6): 1068-1077.e3. https://doi.org/10.1016/j.cmet.2020.04.021. 